\title{
Recent trends in the chemistry of pyridine $\mathbf{N}$-oxides
}

\author{
Shaker Youssif \\ Department of Chemistry, Faculty of Science, Zagazig University, Zagazig, Egypt \\ (received 16 Mar 01; accepted 10 Dec 01; published on the web 18 Dec 01)
}

\begin{abstract}
This review describes the synthesis and reactions of pyridine N-oxides within the last ten years. The first part surveys the different synthetic methods which include ring transformation, classical oxidations using peracids, the use of metalloorganic oxidizing agents and cycloaddition reactions. The second part surveys the reactions of pyridine $\mathrm{N}$-oxides including the deoxygenation, nucleophilic reaction and cycloaddition to $\mathrm{N}-\mathrm{O}$ bond.
\end{abstract}

Keywords: Synthesis of pyridine N-oxides, reactions of pyridine N-oxides, cycloaddition reactions, metallorganic oxidizing agents

Introduction

Spectroscopic properties

1 Synthesis of pyridine N-oxides

1.1 From the esters of N-hydroxy-2-thiopyridone

1.2 By ring transformation of isooxazoles.

1.3. By the oxidation of pyridine derivatives

1.3.1 Using $\mathrm{H}_{2} \mathrm{O}_{2} / \mathrm{AcOH}$

1.3.2 Using $\mathrm{H}_{2} \mathrm{O}_{2}$ / manganese tetrakis(2,6-dichlorophenyl)porphyrin

1.3.3 Using $\mathrm{H}_{2} \mathrm{O}_{2}$ / methyltrioxorhenium (MTO)

1.3.4 Using dimethyldioxirane (DMD)

1.3.5 Using bis(trimethylsilyl)peroxide (BTSP)

1.3.6 Using Caro's acid

1.3.7 Using m-chloroperoxybenzoic acid

1.3.8 Using oxaziridines

1.4 Through cycloaddition reaction

2 Reactions of pyridine N-oxides

2.1 Deoxygenation

2.2 Rearrangement of allyloxypyridine $\mathrm{N}$-oxide

2.3 Nucleophilic reactions

2.4 Metallation followed by electrophilic substitution 
2.5 O- Alkylation.

2.6 Nucleophilic substitution of 3-bromo-4-nitropyridine N-oxide.

2.7 Cycloaddition to dipolar N-O

3 Conclusion

\section{Introduction}

The chemistry and applications of N-oxides have recently received much attention due to their usefulness as synthetic intermediates and their biological importance ${ }^{1}$. Heterocyclic N-oxides are also useful as protecting groups, auxiliary agents, oxidants ${ }^{1}$, ligands in metal complexes ${ }^{2}$ and catalysts ${ }^{1}$.

The N-O moiety of pyridine N-oxides possesses a unique functionality which can act effectively as a push electron donor and as a pull electron acceptor group. This strong push-pull property has an essential chemical consequence; it accounts for the equally easy synthesis of 4substituted derivatives of pyridine $\mathrm{N}$-oxides with donor as well as acceptor groups. The contribution of the resonance forms I and II depends on the nature of the substituent at position 4. The strong electron-acceptor nitro group favors the charge transfer form II. ${ }^{3-5}$
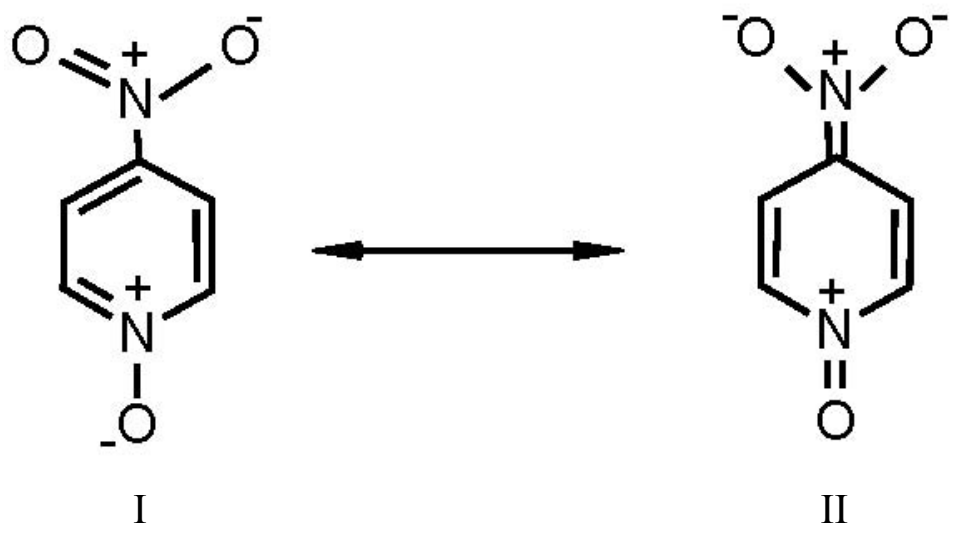

\section{Spectroscopic properties}

For the single pyridine ring hydrogen atom of an isolated molecule three different vibrations are expected, e.g. =C-H stretch, in plane bend and out of plane deformation. The crystal data have shown that there are two different types of $=\mathrm{C}-\mathrm{H}$ bonds in crystal. ${ }^{6}$ The $=\mathrm{C}-\mathrm{H}$ stretch band is split into two components in the Raman spectrum, at 3066 and $3054 \mathrm{~cm}^{-1}$, while IR spectrum shows just one band at $3052 \mathrm{~cm}^{-1}$. The strongest band in the IR spectrum is observed at $1231 \mathrm{~cm}^{-}$ ${ }^{1}$ together with adjacent absorptions at 1238 and $1250 \mathrm{~cm}^{-1}$; and the Raman band at $1252 \mathrm{~cm}^{-1}$ these are assigned to the $\mathrm{N}-\mathrm{O}$ stretch, because this vibration is accompanied by a large change in dipole moment and polarizability. ${ }^{7-8}$ The blue shifted very strong IR band at $1258 \mathrm{~cm}^{-1}$ supports both the assignment to $v(\mathrm{~N}-\mathrm{O})$ and existence of $\mathrm{CH}$... O-N hydrogen bonding. 


\section{UV spectra}

The electronic structures and spectra of heterocyclic amine N-oxides have been extensively studied by many researchers. In the case of pyridine N-oxide, the strong $\pi$ - $\pi^{*}$ band was observed near $280 \mathrm{~nm}$, in aprotic solvents. On going from pyridine $\mathrm{N}$-oxide to 2,6-dimethylpyridine $\mathrm{N}$ oxide this band shows a blue shift to $274 \mathrm{~nm}$. The study of 3-halo-2,6-dimethylpyridine N-oxides has shown that apart from the strong $272-278 \mathrm{~nm}$ band, two or three more bands are observed in the regions 220-240 and 310-330 nm. The third, weak band is observed at $363.3 \mathrm{~nm}$. It might originate from the $n-\pi^{*}$ transition, i.e. excitation from HOMO to either the LUMO or higher MO. This band is observed at a significantly higher energy $(363.3 \mathrm{~nm})$ for 4-chloro-2,6-dimethyl-3iodopyridine N-oxide than for 3-iodo-2,6-dimethyl-pyridine $\mathrm{N}$-oxide (329 nm). ${ }^{9-11}$

\section{Synthesis of pyridine $\mathrm{N}-0 x i d e s$}

\subsection{From the esters of $\mathrm{N}$-hydroxy-2-thiopyridone}

The reaction of diethyl azodicarboxylate (DAD) with a series of the esters of N-hydroxy-2thiopyridone of general formula 1 afforded compounds (2a-e). The irradiation of compounds 2 in acetonitrile with a medium pressure mercury lamp at room temperature for $1-4 \mathrm{~h}$ led to the formation of the corresponding dimers $\mathbf{3}$ as well as the expected disulfides $\mathbf{4}$ as shown in (Scheme 1). ${ }^{12}$ 


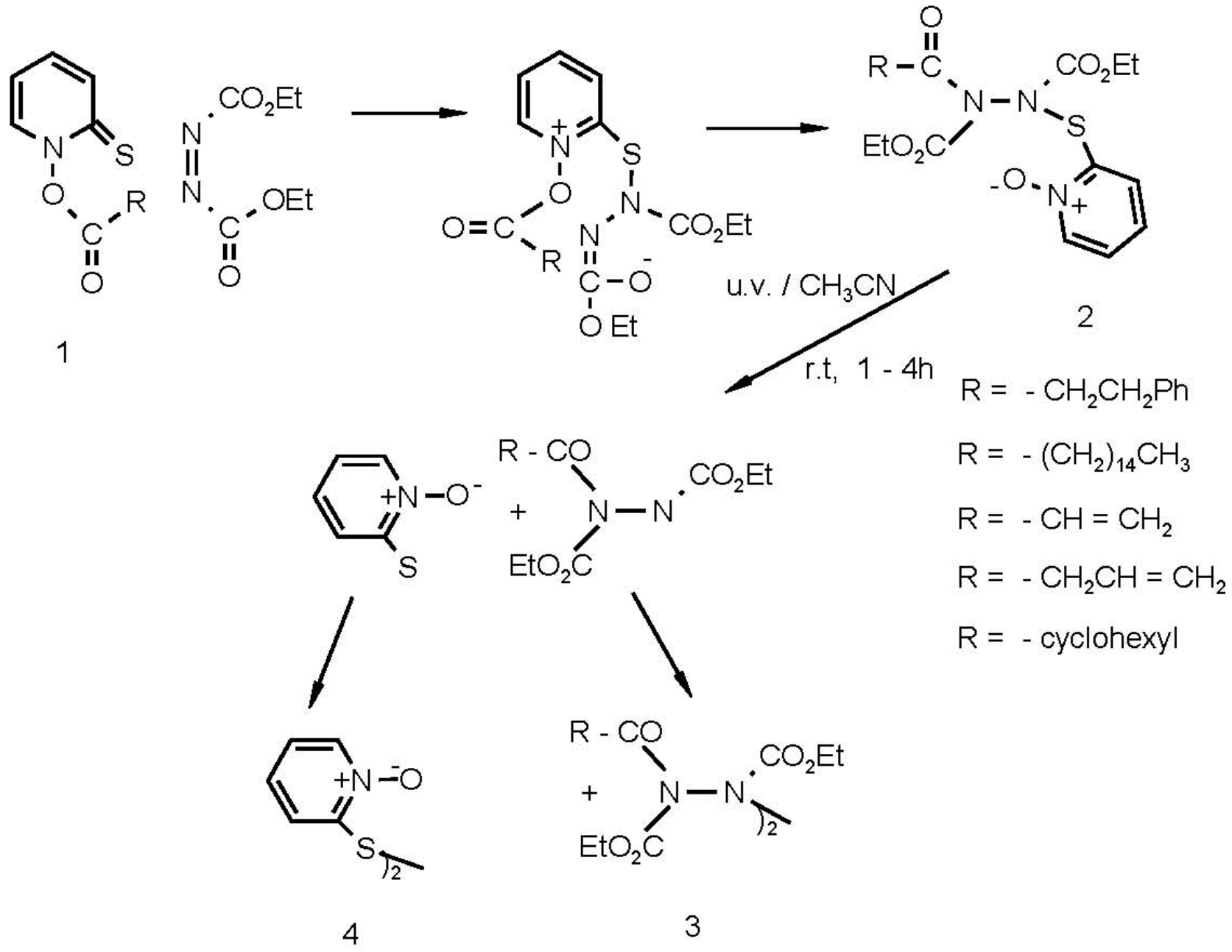

$\mathrm{R}=-\mathrm{CH}_{2} \mathrm{CH}_{2} \mathrm{Ph},-\left(\mathrm{CH}_{2}\right)_{14} \mathrm{CH}_{3},-\mathrm{CH}=\mathrm{CH}_{2},-\mathrm{CH}_{2} \mathrm{CH}=\mathrm{CH}_{2}$, -cyclohexyl

\section{Scheme 1}

\subsection{By ring transformation of isoxazoles}

5-Cyanomethyl-2-isoxazolines (5) were reported to react with catalytic amount of base, such as 1,5-diazobicyclo[5.4.0] undec-5-ene (DBU) in boiling xylene to form 6-substituted-2aminopyridine N-oxides (6). ${ }^{13}$ The transformation should proceed through the cyclization of the reactive Z-vinylene-hydroxylamine spontaneously to give the final product 6. 


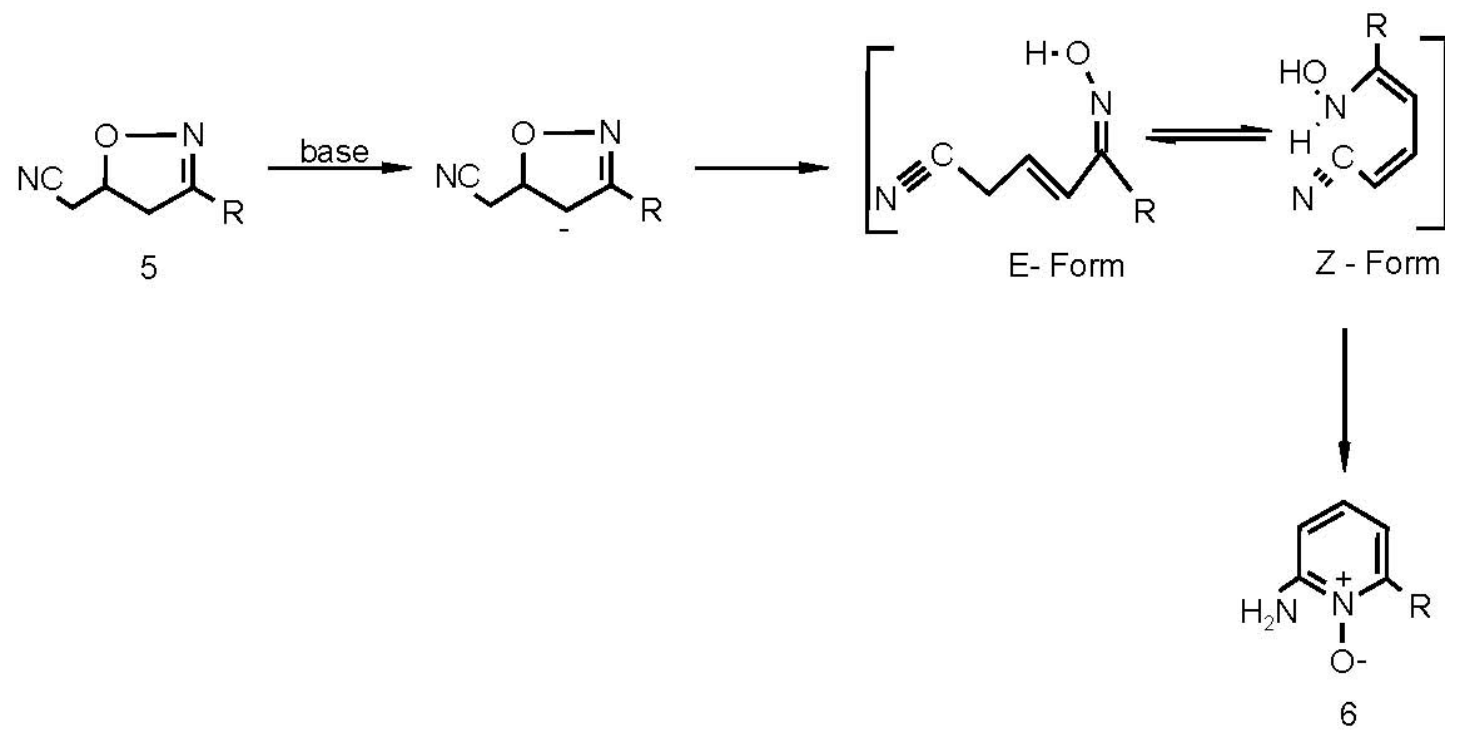

$\mathrm{R}=-\mathrm{Me},-\mathrm{C}_{6} \mathrm{H}_{5},-\mathrm{CH}=\mathrm{CHC}_{6} \mathrm{H}_{5}$

\subsection{By the oxidation of pyridine derivatives}

\subsubsection{Using $\mathrm{H}_{2} \mathrm{O}_{2} / \mathrm{AcOH}$}

Picolinic acid (7) was converted into 4-nitropicolinic acid $\mathrm{N}$-oxide (8), which on treatment with hydrogen chloride in methanol afforded 4-chloropicolinic acid N-oxide (9) ${ }^{14}$.

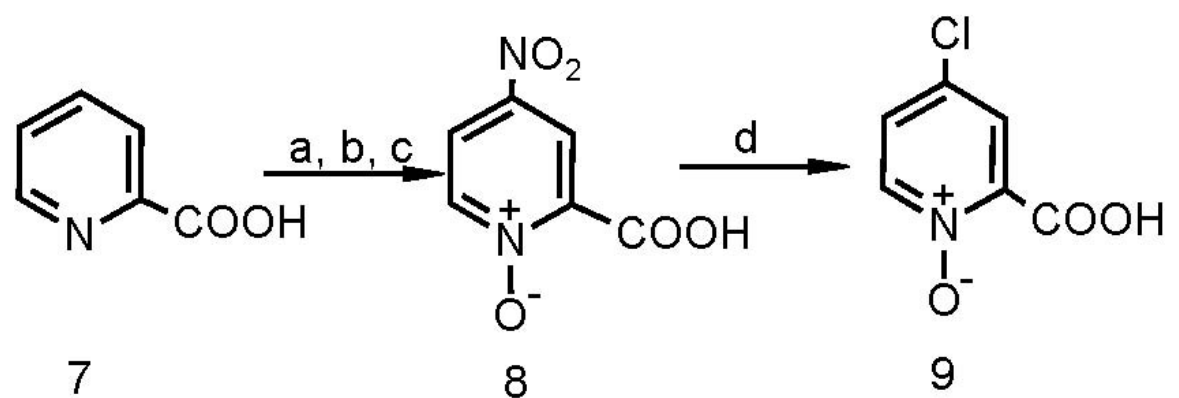

(a) $\mathrm{KOH}$. (b) $\mathrm{H}_{2} \mathrm{O}_{2} /$ AcOH. (c) $\mathrm{HNO}_{3} / \mathrm{H}_{2} \mathrm{SO}_{4}$. (d) $\mathrm{HCl}$.

On the other hand, the isonicotinanilide $\mathrm{N}$-oxide (12) have been prepared from isonicotinic acid (10) via the anilide (11). ${ }^{15}$ 


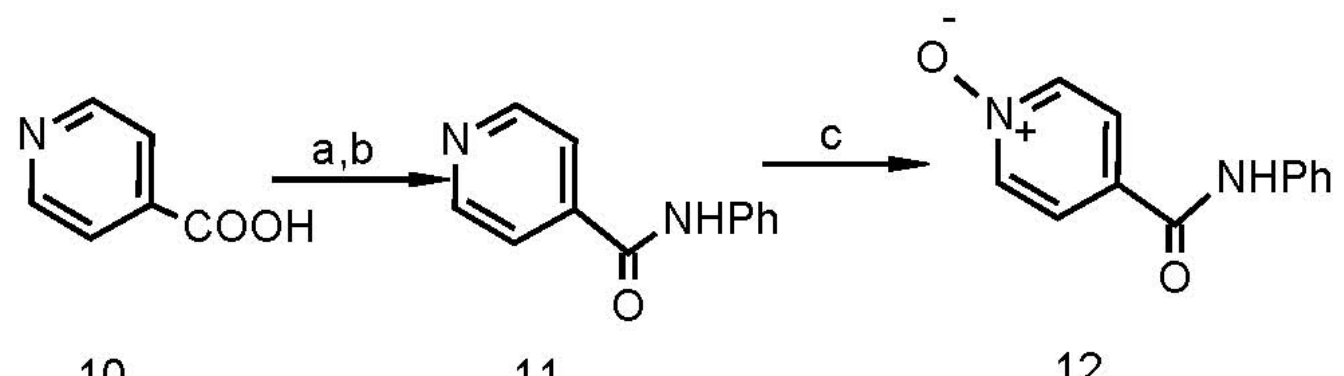

10

11

12

(a) $\mathrm{SOCl}_{2}$. (b) $\mathrm{PhNH}_{2} / \mathrm{Et}_{3} \mathrm{~N} / \mathrm{CHCl}_{3}$. (c) $\mathrm{H}_{2} \mathrm{O}_{2} / \mathrm{AcOH}$.

Oxidation of 2,6-diamino-3,5-dinitropyridine (13) with 30\% aqueous hydrogen peroxide in acetic acid under reflux afforded 2,6-diamino-3,5-dinitropyridine $\mathrm{N}$-oxide (14) in $80 \%$ yield. ${ }^{16,17}$

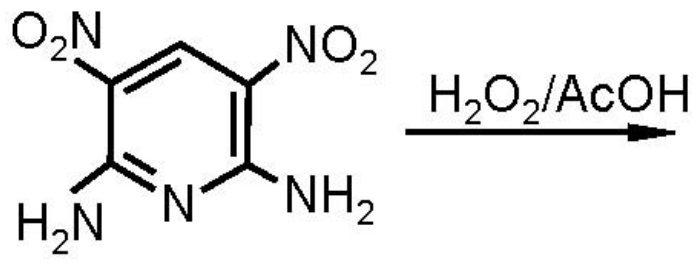

13

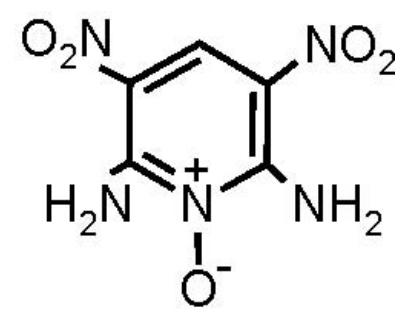

14

\subsubsection{Using $\mathrm{H}_{2} \mathrm{O}_{2} /$ manganese tetrakis(2,6-dichlorophenyl)porphyrin [Mn(TDCPP)Cl]}

A variety of pyridine derivatives 15a-d were converted into their corresponding N-oxides 16a-d in good yields and high chemoselectivity in the presence of hydrogen peroxide as oxygen donor, catalytic amount of manganese tetrakis(2,6-dichlorophenyl) porphyrin [ $\mathrm{Mn}(\mathrm{TDCPP}) \mathrm{Cl}]$ and ammonium acetate as cocatalyst in $\mathrm{CH}_{2} \mathrm{Cl}_{2} / \mathrm{CH}_{3} \mathrm{CN}{ }^{18}$ The pyridines bearing an alkyl substituents shows almost complete conversion to $\mathrm{N}$-oxides rather than pyridines bearing chlorine substituent.

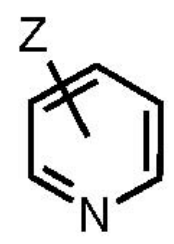

15

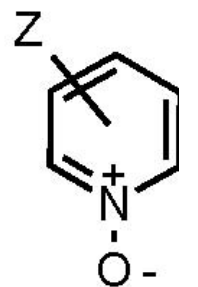

16

(a) $\mathrm{Z}=\mathrm{H}$. (b) $\mathrm{Z}=2-\mathrm{CH}_{3}$. (c) $\mathrm{Z}=4-\mathrm{CH}_{3}$. (d) $\mathrm{Z}=2-\mathrm{Cl}$. 


\subsubsection{Using $\mathrm{H}_{2} \mathrm{O}_{2}$ / methyltrioxorhenium (MTO)}

Pyridines 17a-c are oxidized in high yields to their N-oxides 18a-c by using $30 \%$ aqueous $\mathrm{H}_{2} \mathrm{O}_{2}$ in the presence of catalytic amounts of methyltrioxorhenium (MTO). It was noted that, 3- and 4substituted pyridines, regardless of their electronic nature, gave high yields of the corresponding $\mathrm{N}$-oxides on using only $0.2-0.5 \mathrm{~mol} \%$ of MTO.

On the other hand, the most simple 2-substituted pyridines require high catalyst loading, typically $5 \mathrm{~mol} \%$ to reach both full conversion and high yields. ${ }^{19-28}$<smiles>[X]c1ccncc1</smiles>

17
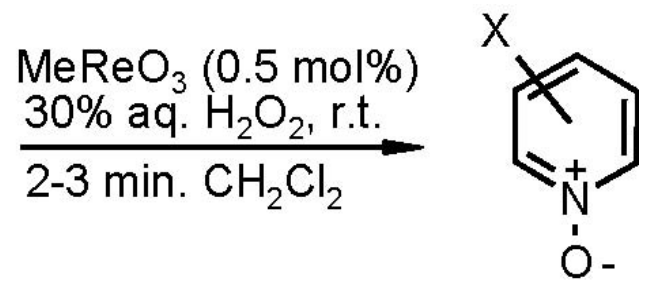

18

(a) $\mathrm{X}=\mathrm{CN}(2-, 3-, 4-)$. (b) $\mathrm{X}=\mathrm{CH}_{3} \mathrm{CO}(3-, 4-)$. (c) $\mathrm{X}=\mathrm{F}(2-)$

\subsubsection{Using dimethyldioxirane (DMD)}

Addition of excess of dimethyldioxirane (DMD), to a solution of pyridines 15a and/or 19a-d in $\mathrm{CH}_{2} \mathrm{Cl}_{2}$ at $0^{\circ} \mathrm{C}$ led to rapid and quantitative conversion to the corresponding $\mathrm{N}$-oxides 16a and 20a-d. $^{23-35}$<smiles>[R]c1cc([R])c([R])c([R])n1</smiles>

$15 a, 19 a-d$

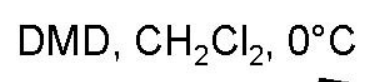<smiles>[R]c1cc([R])[n+]([O-])c([R])c1[R]</smiles>

16a, 20a-d

15a, 16a) $R^{1}=R^{2}=R^{3}=R^{4}=H$

19a, 20a) $\mathrm{R}^{1}=\mathrm{R}^{4}=\mathrm{H}, \mathrm{R}^{2}=\mathrm{R}^{3}=\mathrm{CH}_{3}$

19b, 20b) $\mathrm{R}^{2}=\mathrm{R}^{3}=\mathrm{H}, \mathrm{R}^{1}=\mathrm{R}^{4}=\mathrm{CH}_{3}$

19c, 20c) $\mathrm{R}^{2}=\mathrm{H}, \mathrm{R}^{1}=\mathrm{R}^{3}=\mathrm{R}^{4}=\mathrm{CH}_{3}$

19d, 20d) $R^{1}=R^{2}=R^{4}=H, R^{3}=4$-(3-cyclohexenyl) 


\subsubsection{Using bis(trimethylsilyl)peroxide (BTSP)}

It was found that methyltrioxorhenium MTO can be replaced in the epoxidation process by cheaper and more readily available inorganic rhenium derivatives. Aqueous $\mathrm{H}_{2} \mathrm{O}_{2}$ is also replaced by bis(trimethylsilyl)peroxide (BTSP) ${ }^{36}$. For example, when a mixture of methyl isonicotinate (21) and perrhenic acid in $\mathrm{CH}_{2} \mathrm{Cl}_{2}$ was treated with BTSP and stirred for $6 \mathrm{~h}$ at $24^{\circ} \mathrm{C}$ afforded N-oxide 22.<smiles>COC(=O)c1ccncc1</smiles>

21

$$
\underset{1.5 \text { min., } \mathrm{CH}_{2} \mathrm{Cl}_{2}}{\stackrel{0.5 \mathrm{~mol} \% \mathrm{HOReO}_{3}}{\longrightarrow}}
$$

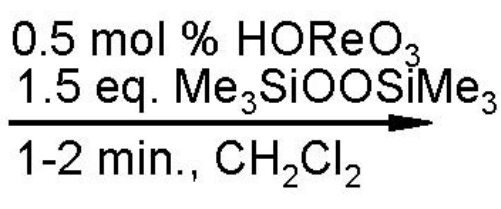

22

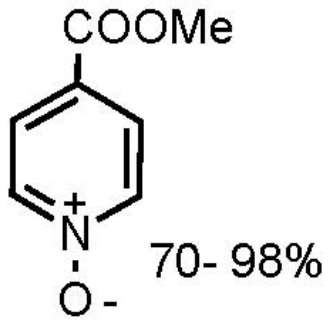

\subsubsection{Using Caro's acid}

The synthesis of aminopyridine $\mathrm{N}$-oxides involved acylation of the amino group, oxidation of the ring nitrogen and deprotection has been reported ${ }^{1}$. The use of Caro's acid (peroxomonosulfuric acid, $\mathrm{H}_{2} \mathrm{SO}_{5}$ ) allows two useful variations: a)The reaction can be carried out over a wide $\mathrm{pH}$ range and b) The reaction can be carried out in water. It has been shown that, the reactions take place under neutral or basic conditions. When aminopyridines 23 were dissolved in $\mathrm{KOH}$ and Caro's acid was added slowly at room temperature with stirring the corresponding N-oxides 24 were isolated. ${ }^{37 a}$<smiles>[R]c1nc([R7])c([R])c([R])c1[R]</smiles>

23<smiles>[R]c1c([R])c([R])[n+]([O-])c([R])c1[R]</smiles>

$\begin{array}{lllll}\mathrm{R}^{1} & \mathrm{R}^{2} & \mathrm{R}^{3} & \mathrm{R}^{4} & \mathrm{R}^{5} \\ \mathrm{NH}_{2} & \mathrm{H} & \mathrm{H} & \mathrm{H} & \mathrm{H} \\ \mathrm{NH}_{2} & \mathrm{H} & \mathrm{Me} & \mathrm{H} & \mathrm{H} \\ \mathrm{H} & \mathrm{H} & \mathrm{NMe}_{2} & \mathrm{H} & \mathrm{H}\end{array}$




\subsubsection{Using m-chloroperoxybenzoic acid (MCPBA)}

Treatment of 3-trichloromethylpyridine (25) with m-chloroperoxybenzoic acid (m-CPBA) in dry chloroform gave 3-trichloromethyl-pyridine N-oxide (26). ${ }^{37 \mathrm{~b}}$

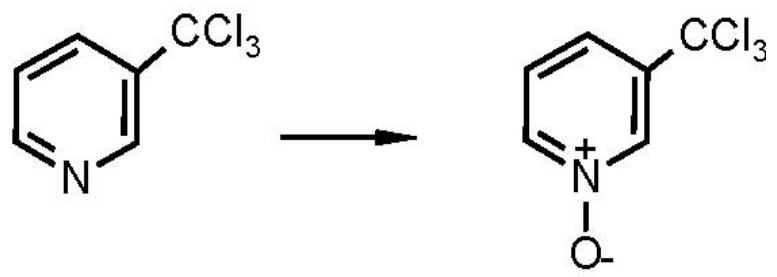

25

26

The oxidation of heterocyclic compounds by $\mathrm{m}-\mathrm{CPBA} / \mathrm{HCl} / \mathrm{DMF}$ system has been reported. ${ }^{38-42}$ For example the N-oxidation of some pyridines with m-CPBA in DMF/MeOH in the presence of $\mathrm{HF}$ afforded their $\mathrm{N}$-oxides in excellent yields ${ }^{43}$. The $\mathrm{N}$-oxidation of 3,5-lutidine (27) and nicotinic acid (28) gave their $\mathrm{N}$-oxides 29 and 30, respectively in excellent yields.

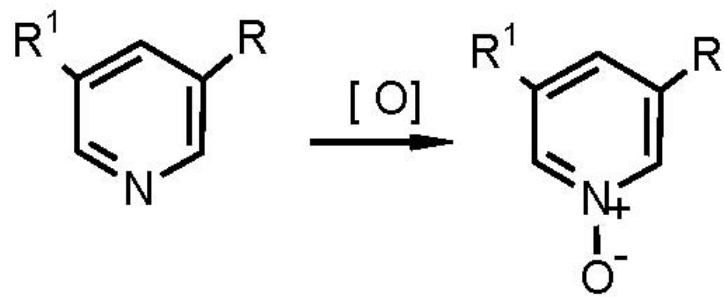

$27 \mathrm{R}=\mathrm{R}^{1}=\mathrm{CH}_{3} 29$

$28 \mathrm{R}=\mathrm{COOH}, \mathrm{R}^{1}=\mathrm{H} 30$

The oxidation of 3-substituted pyridines (31) to their corresponding pyridine N-oxides 32 using (m-CPBA) gave the highest yield when compared to other oxidizing agents such as $30 \%$ $\mathrm{H}_{2} \mathrm{O}_{2}$ in glacial acetic acid, sodium perborate monohydrate, potassium peroxymonosulfate and magnesium monoperoxy-phthalate. ${ }^{44-46}$ 
<smiles>[R]c1cccnc1</smiles>

31

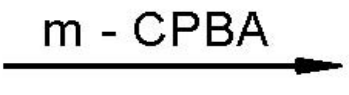<smiles>[R]c1ccc[n+]([O-])c1</smiles>

(a) $\mathrm{R}=\mathrm{CH}_{2}$ COOEt. (b) $\mathrm{R}=\mathrm{CH}_{2} \mathrm{CH}_{3}$. (c) $\mathrm{R}=\mathrm{CONH}_{2}$.

\subsubsection{Using oxaziridines}

Perfluoro-(cis-2,3-dialkyloxaziridine) (33) proved to be versatile oxidizing agents ${ }^{47}$, being powerful enough to give a clean oxyfunctionalization. So, the oxygenation of the heteroatom site of substrates 15a, 34b-c to give N-oxides (16a,35b-c) has been observed for all tested substrates and in some cases amination of the same site also occurred to give variable amounts of $\mathrm{N}$ aminides (36a-c).<smiles>[R]c1ccnc([R7])c1[R]</smiles>

15a, 16a, 36a $\mathrm{R}^{1}=\mathrm{R}^{2}=\mathrm{R}^{3}=\mathrm{H}$

34b, 35b,36b R ${ }^{1}=\mathrm{R}^{2}=\mathrm{H}, \mathrm{R}^{3}=\mathrm{CH}_{3}$

34c, 35c,36c $\mathrm{R}^{1}=\mathrm{R}^{2}=\mathrm{H}, \mathrm{R}^{3}=\left(\mathrm{CH}_{3}\right)_{2} \mathrm{CH}$

The formation of $\mathrm{N}$-aminides (36) have been performed according to the following mechanism: 
<smiles>[R]c1ccnc([R])c1[R]</smiles>

$15 a, 33 b-c$

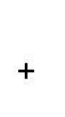<smiles>FC(F)(F)N1OC1(F)C(F)(F)F</smiles>

$34 b-c$<smiles>[R]c1cc[n+](N=C=C(F)F)c([R])c1[R]</smiles><smiles>[R]c1cc[n+](N(C)C(F)(F)F)c([R])c1[R]</smiles><smiles>[R]c1cc[n+](NC(F)(F)C(F)(F)F)c([R])c1[R]</smiles><smiles></smiles><smiles>O=C(F)C(F)(F)F</smiles>
$+\mathrm{H}_{2} \mathrm{O},-\mathrm{HF}$<smiles>[R]c1cc[n+](NC(O)(F)C(F)(F)F)c([R])c1[R]</smiles>

$-\mathrm{HF}$<smiles>[R]c1cc[n+](N(C)C(=O)C(F)F)c([R])c1[R]</smiles>

$36 \mathrm{a}-\mathrm{c}$

\subsection{Through cycloaddition reactions}

4-Nitroisoxazoles (37) substituted at position 5 easily undergo $[2,4]$ cycloaddition reaction, leading to polynuclear heterocyclic systems. ${ }^{48-50}$ When compounds 37 were allowed to react with an equimolecular amount of 4-(1-cyclopenten-1-yl)morpholine (38) in alcohol at room temperature, the bicyclic pyridine $\mathrm{N}$-oxide (39) were obtained in moderate yield. ${ }^{51}$ 


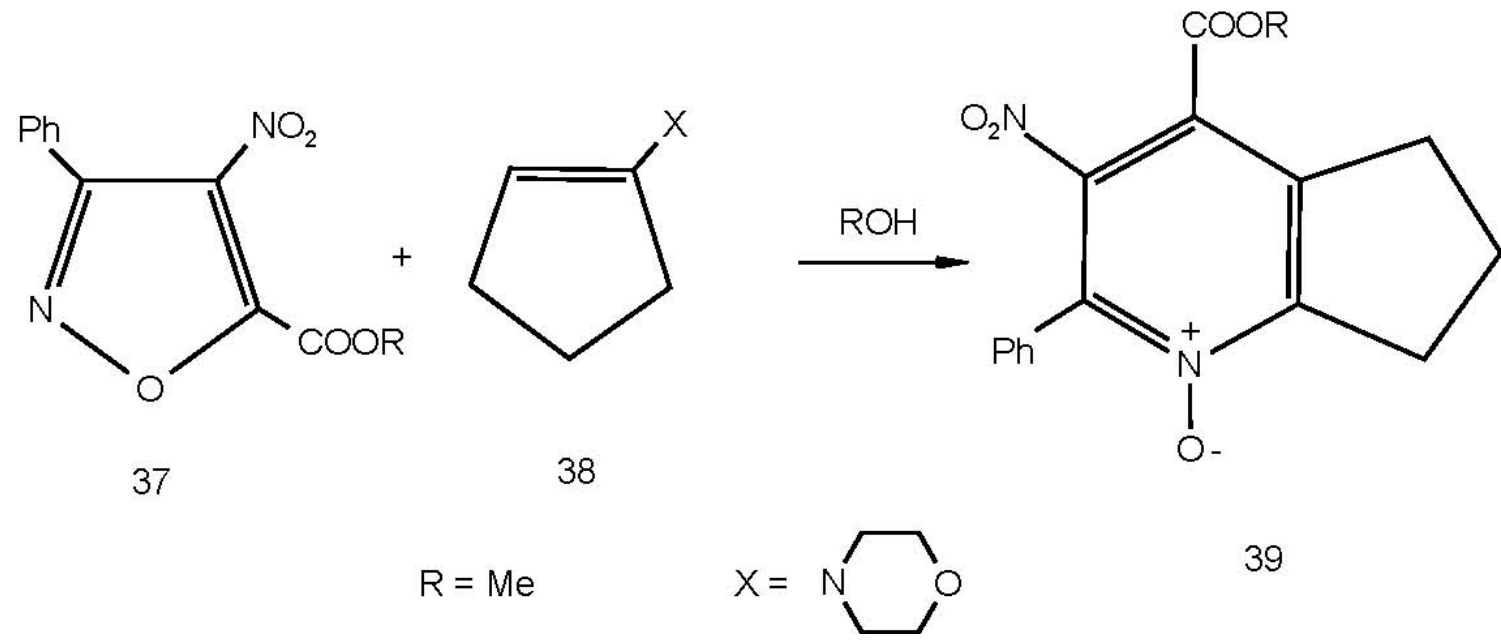

The formation of (39) has been performed according to the following mechanism:
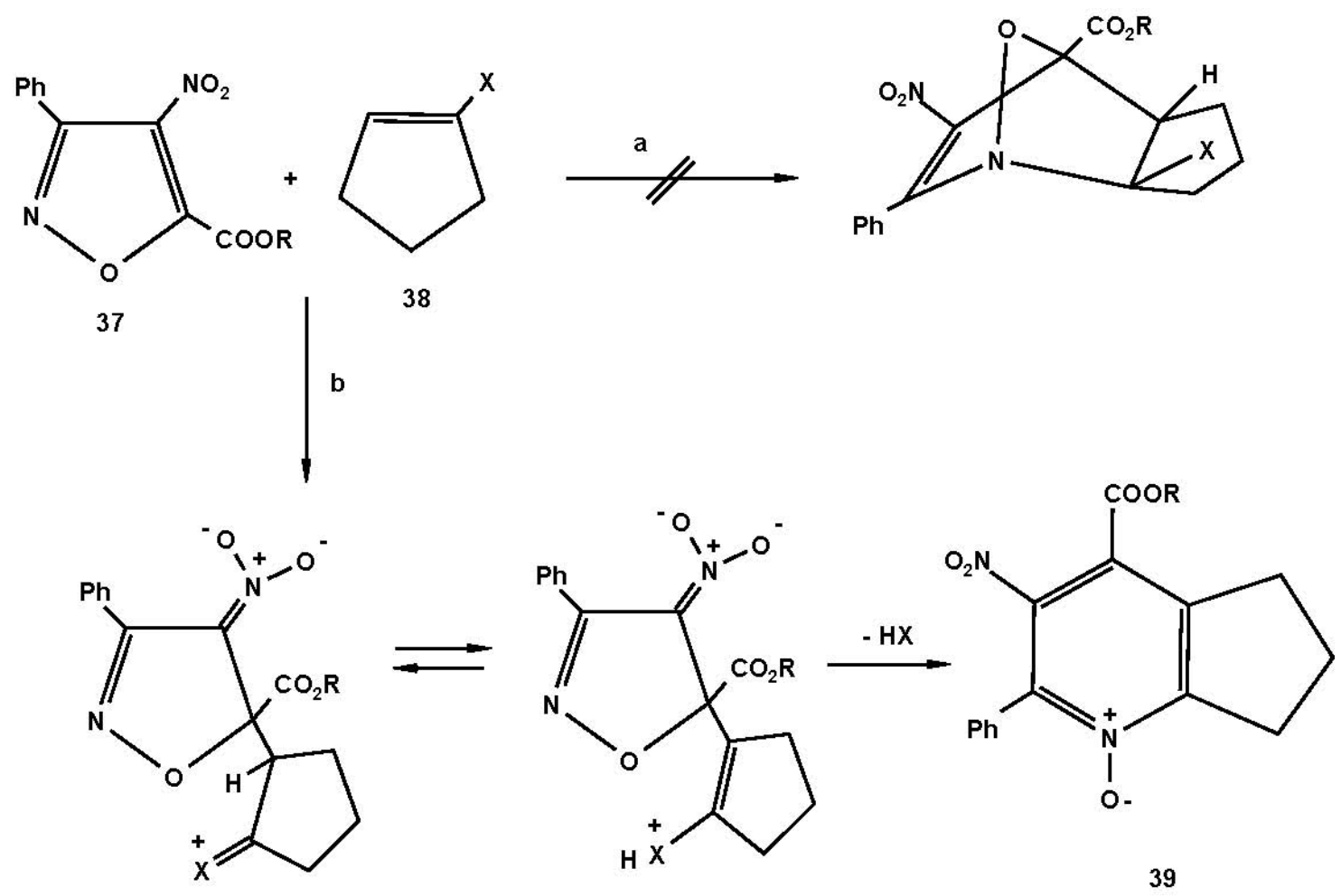


\section{Reactions of pyridine $\mathrm{N}$-oxides}

\subsection{Deoxygenation}

The deoxygenation of aromatic N-oxides, which are important in the syntheses of nitrogenous aromatic heterocycles have been reported. ${ }^{52-60}$ The reaction of 2,6-dimethylpyridine N-oxide hydrochloride (40) with phosphorus oxychloride in the presence of potassium carbonate led to the formation a mixture of $\mathbf{4 1}$ and $\mathbf{4 2}$. Treatment of the mixture with triethylamine converted the more reactive $\mathbf{4 1}$ to quaternary salt $\mathbf{4 3}$ which upon treatment with water gave $\mathbf{4 2}$ in (61\%) yield. ${ }^{61}$<smiles>Cc1cccc(C)[n+]1[O-]</smiles>

40

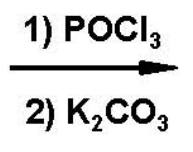

41

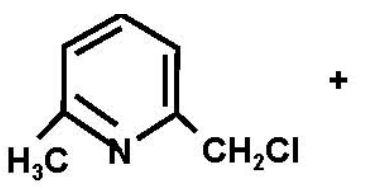

1<smiles>Cc1cccc(C)n1</smiles>

42

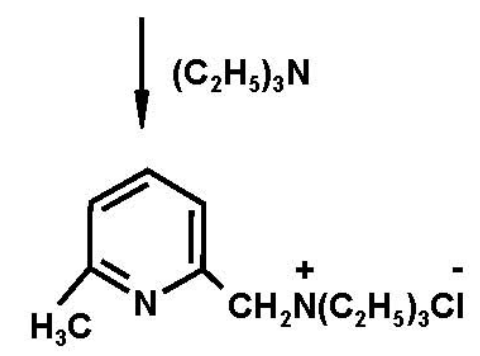

43

The addition of trifluoroacetic acid anhydride to a suspension solution of 4-cyanopyridine Noxide (44) and $\mathrm{NaI}$ in $\mathrm{CH}_{3} \mathrm{CN}$ afforded the formation of 4-cyanopyridine (45). ${ }^{62-63}$

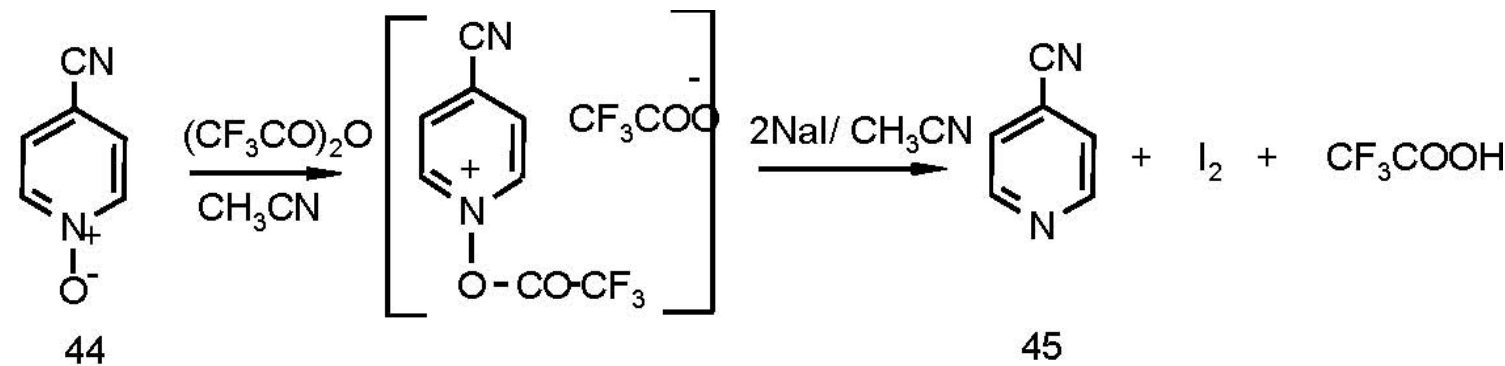

It was found that aluminum iodide can be used as an economic and convenient reagent for the reductive cleavage of $\mathrm{N}-\mathrm{O}$ bond in heterocycles. The reaction of aluminum iodide with pyridine $\mathrm{N}$-oxides 16a and 46 afforded products 15 a and 47 , respectively in high yields. ${ }^{64-65}$ 


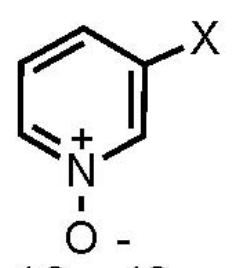

$16 a, 46$
1) $\mathrm{All}_{3} / \mathrm{CH}_{3} \mathrm{CN}$

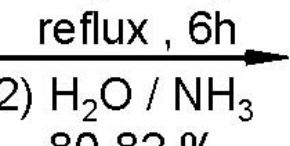
$80-82 \%$<smiles>[X]c1cccnc1</smiles>

$15 a, 47$

15a $\mathrm{X}=\mathrm{H} ; 47 \mathrm{X}=\mathrm{Cl}$

In some cases the resulting $\mathrm{N}$-oxide efficiently decomposes the dioxirane with liberation of oxygen gas and regeneration of heteroarene. The deoxygenation of $\mathrm{N}$-oxides by dioxirane proceeds by an $\mathrm{S}_{\mathrm{N}}{ }^{2}$ attack of the nucleophilic N-oxide oxygen atom on the dioxirane peroxide bond as shown below. 4-N,N-Dimethylaminopyridine N-oxide (24c) was partially deoxygenated by dimethyldioxirane (DMD) to the corresponding amine (23c). ${ }^{29}$

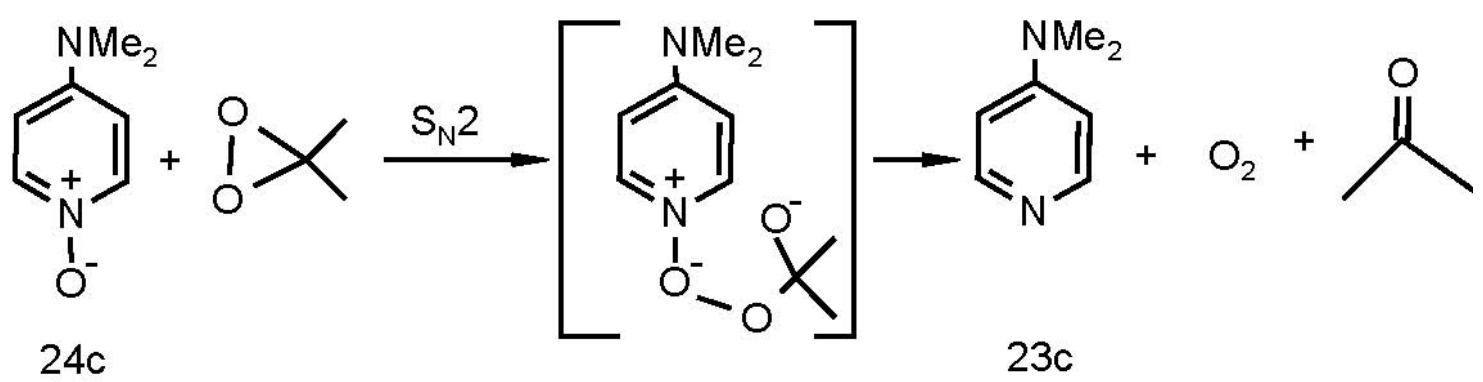

The best results were reported for the deoxygenation of pyridine $\mathrm{N}$-oxides, when the reaction of compound $\mathbf{4 8}$ was carried out using zinc $(4.5 \text { eq. })^{66}$ gave $\mathbf{4 9}$.

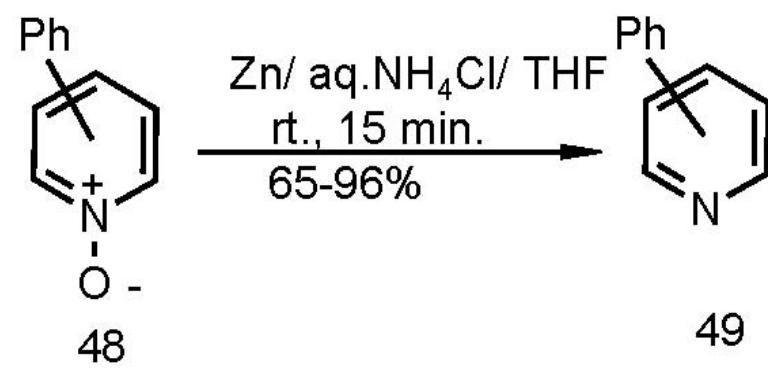

The reduction products of p-nitropyridine $\mathrm{N}$-oxide (50) depends on the concentration of reducing agent. Thus, the reduction of $\mathbf{5 0}$ with 3 molar equivalents of $\mathrm{TiCl}_{4} / \mathrm{SnCl}_{2}$ affords the azocompound (51) in almost quantitative yield. When 2 molar equivalents of the reagent were used, the reaction afforded 4,4'-azopyridine 1,1'-dioxide (52) as the exclusive product. The increasing of $\mathrm{SnCl}_{2}$ amount in the reagent $\left(\mathrm{TiCl}_{4}: \mathrm{SnCl}_{2}\right.$ ratio $=1: 2$, reagent $: \mathrm{N}$-oxide ratio $\left.=3: 1\right)$ results in the formation of 4-pyridinamine (53) in high yield. ${ }^{67-69}$ 


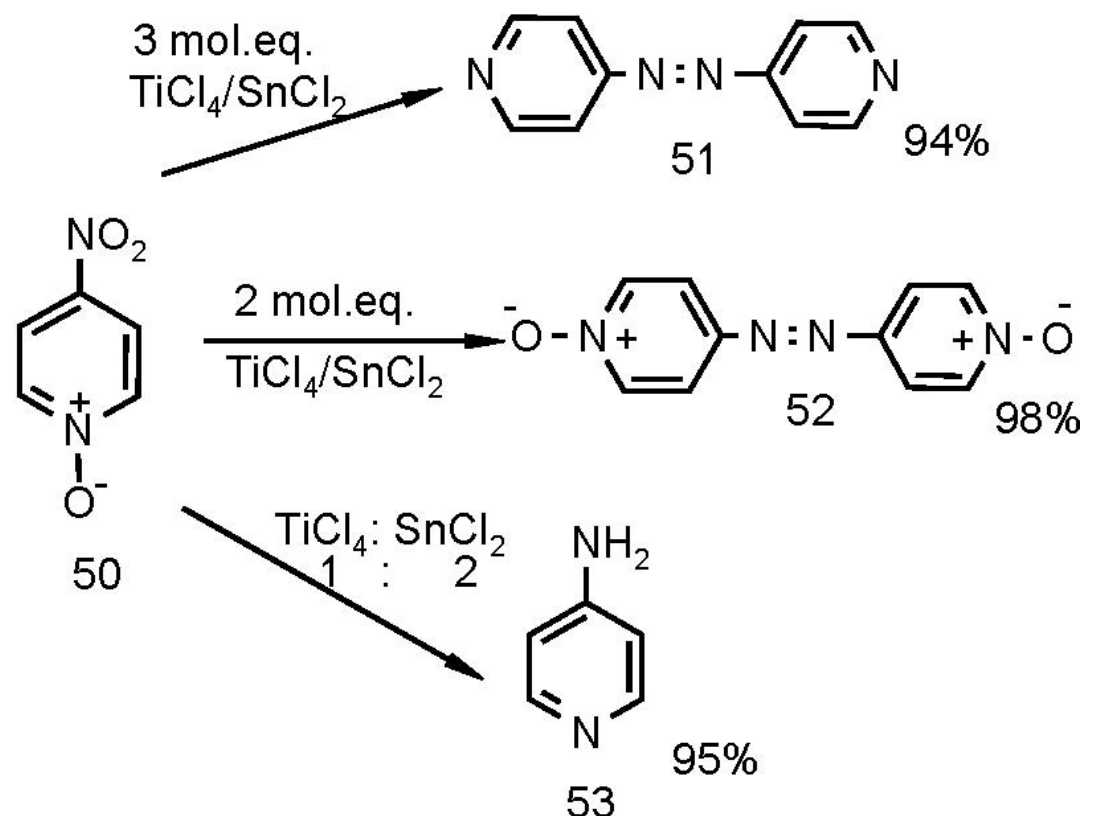

\subsection{Rearrangement of allyloxypyridine $\mathrm{N}$-oxide}

Thermal rearrangement of 2-allyloxypyridine $\mathrm{N}$-oxide (54) yields $\mathrm{N}$-allyloxy-2-pyridones (55) and 3- allyl-N-hydroxy-2-pyridones (56). ${ }^{70-72}$ These transformation are shown to be regiospecific and the reactions involve concerted $[1,4]$ and $[3,3]$ sigmatropic rearrangements.
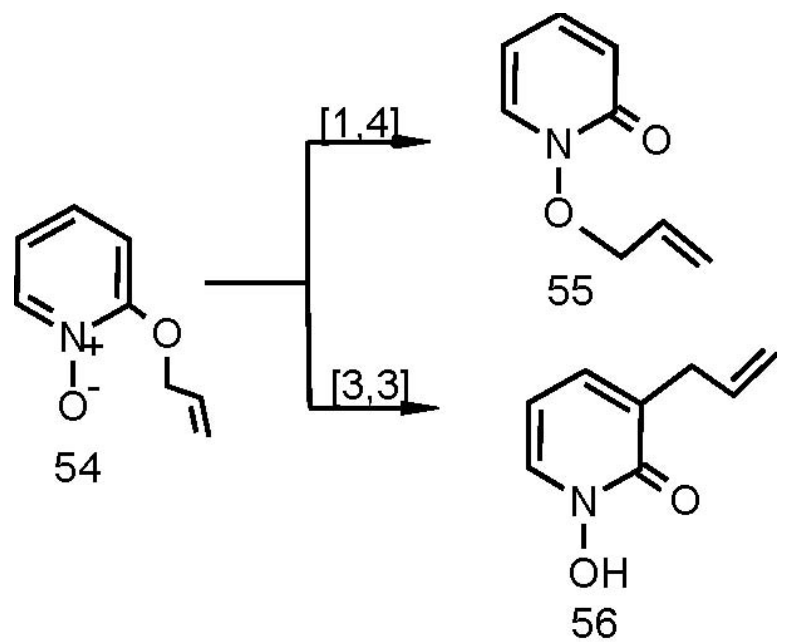

\subsection{Nucleophilic reactions}

The reaction of 2-amino-3-ethoxycarbonyl-5-(4-pyridyl)pyridine N-oxide (57) with ethylmalonylchloride (58) in methylene chloride at room temperature affords the corresponding 2-ethoxycarbonyl-acetamidopyridine $\mathrm{N}$-oxide (59) and the oxadiazole derivative (60). ${ }^{73}$ 
<smiles>CCOC(=O)c1cc(-c2ccncc2)c[n+]([O-])c1N</smiles>

57

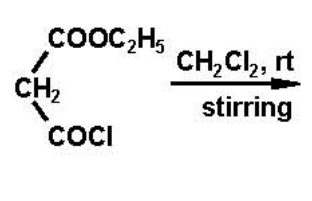

58

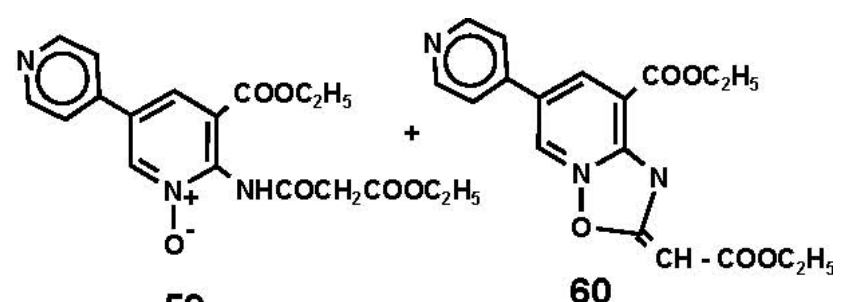

59

60

3,5-Difluoropyridine (61) was converted into its $\mathrm{N}$-oxide $\mathbf{6 2}$ in order to activate the system to electrophilic attack. Nitration of $\mathbf{6 2}$ gave the 4-nitro derivative $\mathbf{6 3}$ as the major isomer, together with the 2-nitro isomer $\mathbf{6 4}$. Treatment of $\mathbf{6 3}$ and $\mathbf{6 4}$ with ammonia gave the amino derivatives $\mathbf{6 5}$, 66 and 67. Thus, the synthetic value of this reaction was demonstrated when the reaction was carried out with 3,5-dichloropyridine (68), which upon nitration gave the nitro compound 69. Treatment of 69 with ammonia resulted in the formation amino derivative 70 as shown in Scheme $2 .{ }^{74}$
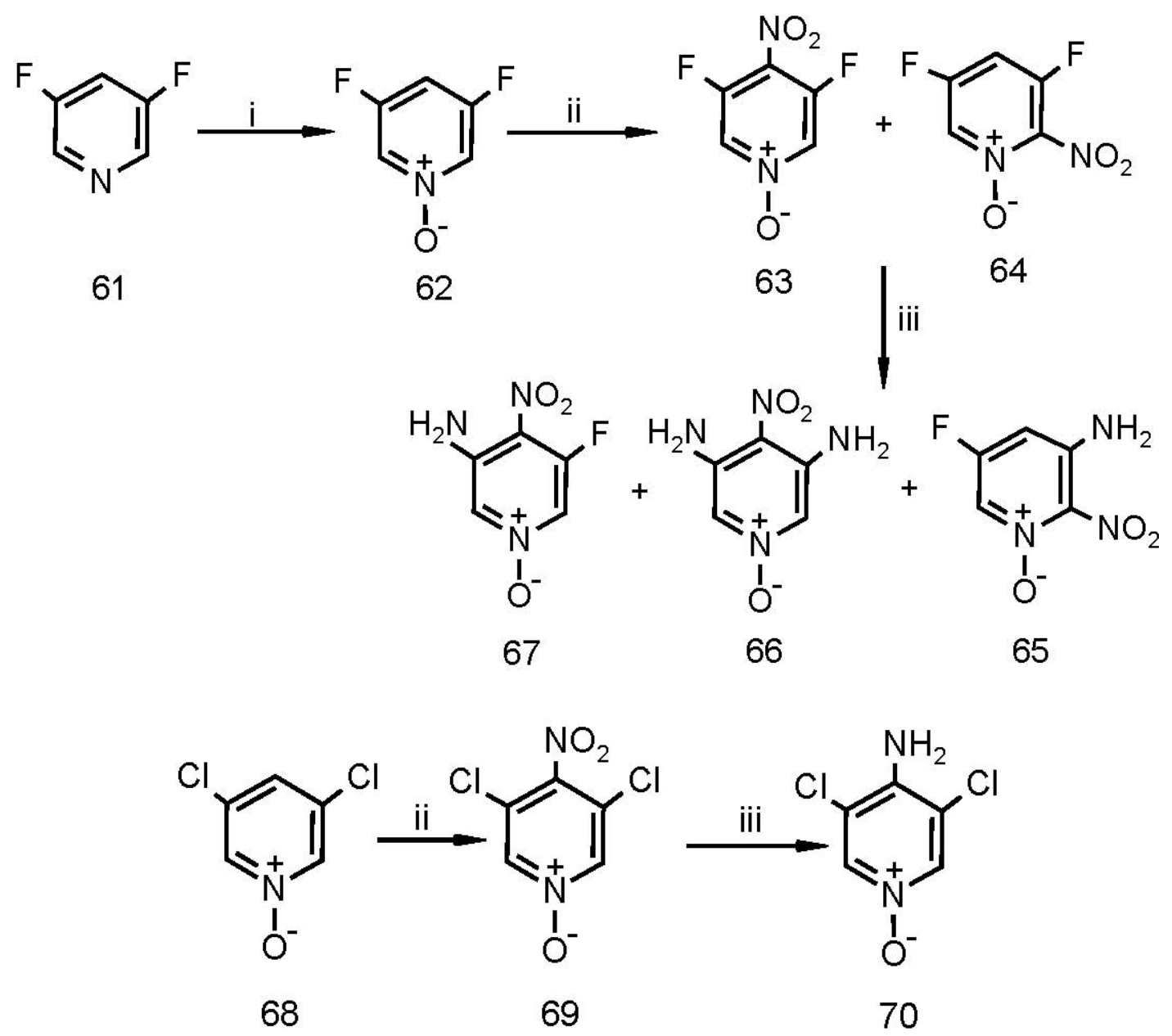

(i) $\mathrm{H}_{2} \mathrm{O}_{2} / \mathrm{AcOH}$. (ii) Fuming $\mathrm{H}_{2} \mathrm{SO}_{4} \cdot \mathrm{HNO}_{3}$. (iii) $\mathrm{NH}_{3} / \mathrm{CH}_{3} \mathrm{CN}$.

\section{Scheme 2}


Displacement of chlorine in 4-chloropyridine N-oxide (71) to give the quaternary salt (72), could be achieved upon treatment with pyridine (15a) in tetracyanoethylene (TCNE). ${ }^{75}$<smiles>[O-][n+]1ccc(Cl)cc1</smiles>

71

$15 a$<smiles>[O-][n+]1ccc(-[n+]2ccccc2)cc1</smiles>

72

The reaction of 3-trichloromethylpyridine N-oxide (26) with 1.5 eq of sodium methoxide in tetrahydrofuran (THF) afforded a mixture of 73a and 73b. When 4.5 eq of sodium methoxide was reacted with 31, a mixture of 73a, 73b and 73c was obtained. Similarly, the reaction with methyl thioglycolate or 2-mercaptoethanol in triethylamine at room temperature afforded 73d and $73 \mathbf{e}^{37 \mathrm{~b}}$

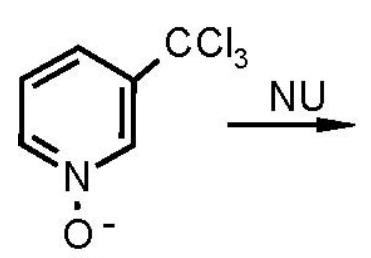

26<smiles>[R]c1ccc([R])[n+]([O-])c1</smiles>

73a $\mathrm{R}^{1}=-\mathrm{OMe}, \mathrm{R}^{2}=-\mathrm{CH}(\mathrm{OMe})_{2}$

73b $\mathrm{R}^{1}=-\mathrm{OMe} \mathrm{R}^{2}=-\mathrm{CHCl}_{2}$

73c $\mathrm{R}^{1}=-\mathrm{OMe} \quad \mathrm{R}^{2}=-\mathrm{C}(\mathrm{OMe})_{3}$

73d $\mathrm{R}^{1}=-\mathrm{SCH}_{2} \mathrm{COOMe}, \mathrm{R}^{2}=-\mathrm{CHCl}_{2}$

73e $\mathrm{R}^{1}=-\mathrm{SCH}_{2} \mathrm{CH}_{2} \mathrm{OH}, \mathrm{R}^{2}=\mathrm{CHCl}_{2}$

\subsection{Metallation followed by electrophilic substitution}

Lithiation of 2-N,N-diisopropylcarboxamidopyridine N-oxide (74a) and 2-pivaloylaminopyridine N-oxides (74b) and (74c) with lithium diisopropylamide (LDA) in tetrahydrofuran (THF) at $-75^{\circ} \mathrm{C}$ resulted in the formation of 75 . Carboxamides and pivaloylamino groups are known to be ortho-directing groups under other conditions. ${ }^{76-77}$ Reaction of various electrophiles namely, benzaldehyde, iodine, carbon dioxide and deuterated ethanol with the intermediate lithio species provided the corresponding compounds $\mathbf{7 5}$. 


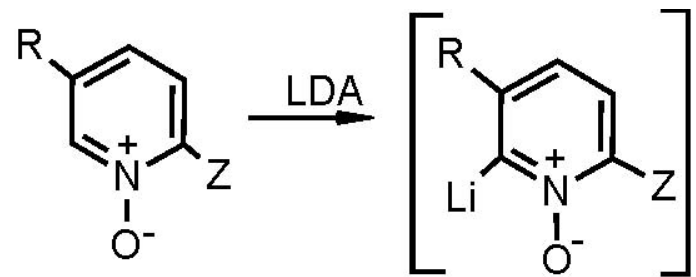

74

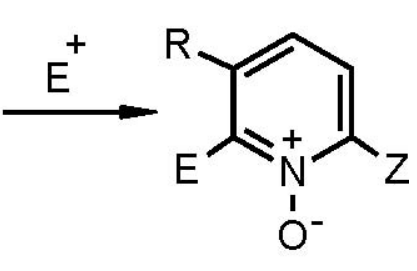

75

a $\mathrm{Z}=\mathrm{CONPr}_{2}^{\mathrm{i}}, \mathrm{R}=\mathrm{H} \mathrm{E}=-\mathrm{CH}(\mathrm{OH}) \mathrm{Ph}$

$\mathrm{b} Z=\mathrm{NHCOBu}^{\mathrm{t}} \mathrm{R}=\mathrm{H} \mathrm{E}=-\mathrm{I}$

$\mathrm{c} Z=\mathrm{NHCOBu}^{\mathrm{t}} \mathrm{R}=\mathrm{Me} \mathrm{E}=-\mathrm{COOH}$

$\mathrm{E}=-\mathrm{D}$

It has been reported that the reaction of butyl lithium with 3,4-dimethoxypyridine $\mathrm{N}$-oxide (76) undergoes a regioselective metallation at C-2. Compound 76 was lithiated with 2.2 eq of butyl lithium in THF at $0^{\circ} \mathrm{C}$ for $45 \mathrm{~min}$. to give an intermediate lithio species which on reaction with various electrophiles afforded the corresponding 2-,6- or 2,6-functionalized products 77, 78, and 79 respectively. ${ }^{78}$

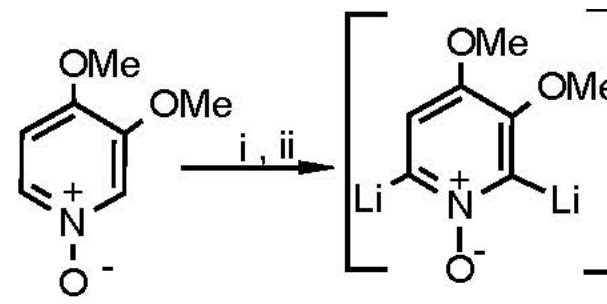

76

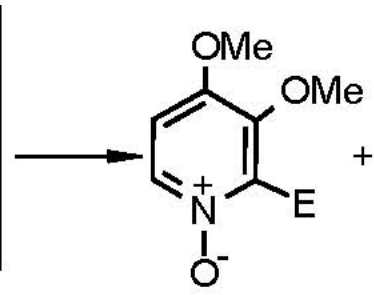

77<smiles>COc1cc(OC)[n+]([O-])c(F)c1OC</smiles>

78

79

$\mathrm{a} ; \mathrm{E}=\mathrm{D} \quad \mathrm{c} ; \mathrm{E}=2-\mathrm{MeC}_{6} \mathrm{H}_{4} \mathrm{CH}(\mathrm{OH})$

b; $\mathrm{E}=\mathrm{MeCH}(\mathrm{OH}) \mathrm{d} ; \mathrm{E}=\mathrm{I}$

$\mathrm{i}=\mathrm{BuLi}$, THF, $0^{\circ} \mathrm{C}, 45 \mathrm{~min}$; ;i, electrophile, $-75^{\circ}$.

When compound 14 was treated with hydroxylamine hydrochloride in aqueous $\mathrm{KOH}$, it afforded compound (80) in 39\% yield. ${ }^{16}$ The process of amination took place by indirect nucleophilic substitution, since the amino group was introduced from hydroxylamine or 4amino-1,2,4-triazole. ${ }^{79}$ Nitration of 3,5-dimethoxypyridine N-oxide (81) gave 3,5-dimethoxy2,6-dinitropyridine N-oxide (82) . Aminolysis of $\mathbf{8 2}$ gave 84, rather than the expected 3,5diamino-2,6-dinitropyridine N-oxide (83). 
<smiles></smiles>

14

80<smiles>COc1cc(OC)c[n+]([O-])c1</smiles>

81<smiles>COc1cc(OC(=O)CNc2c(OC)cc(OC)c([N+](=O)[O-])[n+]2[O-])[n+]([O-])c(N)c1[N+](=O)[O-]</smiles>

82

84<smiles>Nc1cc(N)c([N+](=O)[O-])[n+]([O-])c1[N+](=O)[O-]</smiles>

2-Nitroaminopyridine $\mathrm{N}$-oxides (85) were converted to 2-amino-5-nitro-pyridine $\mathrm{N}$-oxides (86) ${ }^{80}$ in the presence of sulfuric acid at $80^{\circ} \mathrm{C}$.

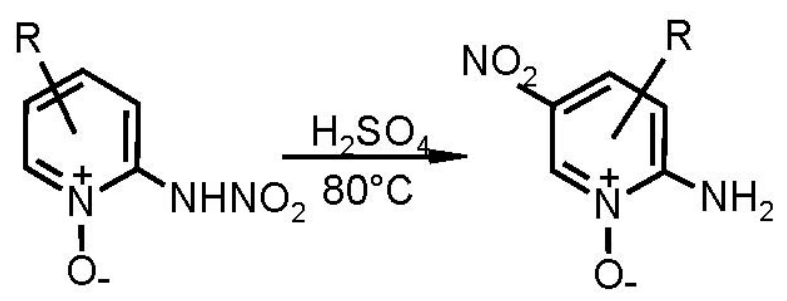

85

86

$\mathrm{R}=\mathrm{H}, 3-\mathrm{Me}, 4-\mathrm{Me}, 6-\mathrm{Me}$

\subsection{O- Alkylation}

The alkylation of pyridine $\mathrm{N}$-oxides 87 with alkyl halides 88 in acetonitrile at $25^{\circ} \mathrm{C}$ afforded the $\mathrm{N}$-alkyloxypyridinium halides $\mathbf{8 9} .{ }^{81-82}$ 


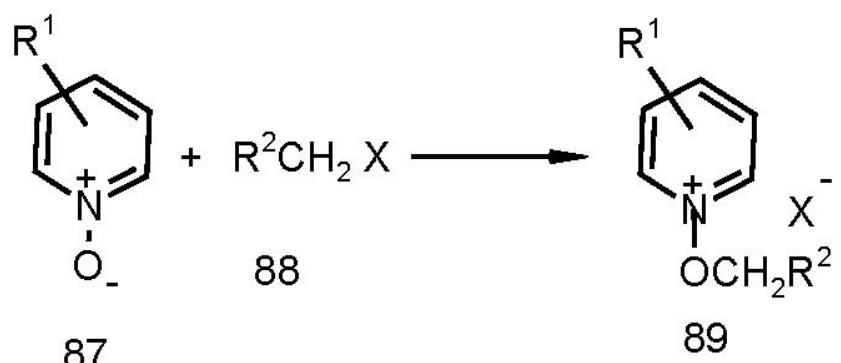

$\mathrm{R}^{1}=\mathrm{Me}, \mathrm{MeO}, \mathrm{Me}_{2} \mathrm{~N} ; \mathrm{R}^{2}=\mathrm{H}, \mathrm{Me}, \mathrm{Ph}, \mathrm{PhCO} ; \mathrm{X}=\mathrm{I}, \mathrm{Br}$

\subsection{Nucleophilic substitution of 3-bromo-4-nitropyridine N-oxide}

Heating of 3-bromo-4-nitropyridine N-oxide (90) with potassium salt of 3-hydroxypyridines (91) in anhydrous DMF at room temperature, afforded 4-nitro-3,3'-oxybispyridine N-oxide (92). Repeating the above experiment in methanol gave 3-bromo-4-methoxypyridine $\mathrm{N}$-oxide $(\mathbf{9 3}){ }^{83}$
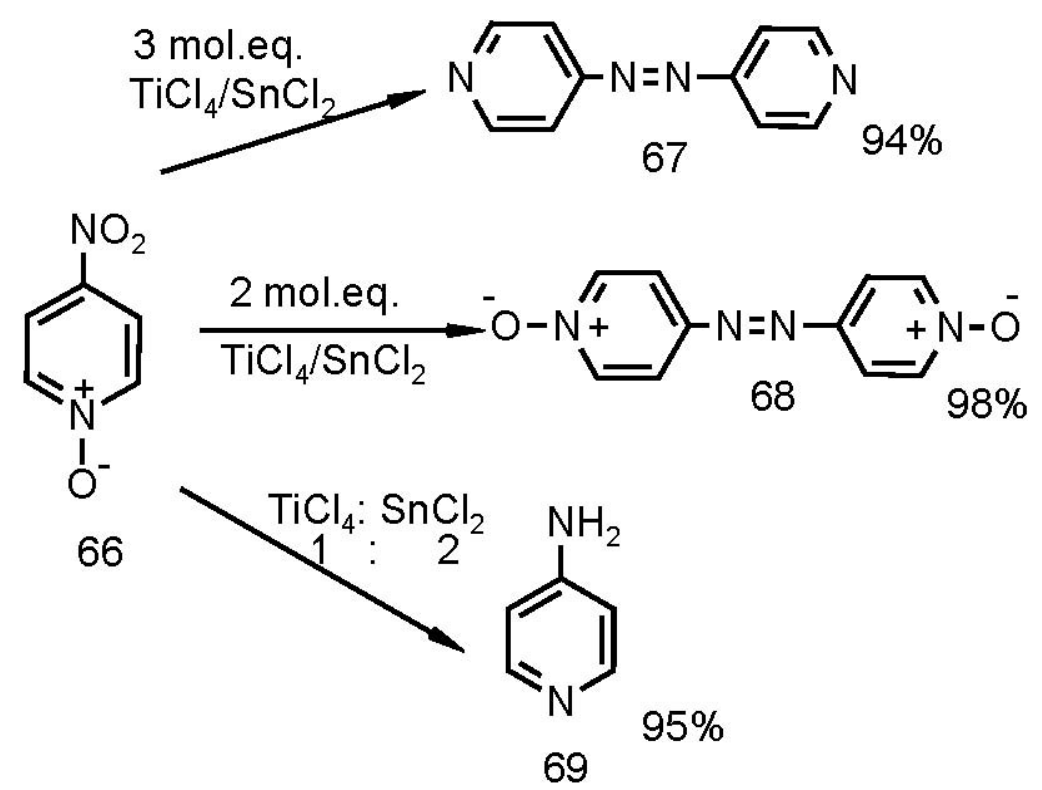

$\mathrm{R}=\mathrm{Me}, \mathrm{CH}_{2} \mathrm{Ph}, \mathrm{CH}_{2} \mathrm{Ph}-4-\mathrm{CF}_{3}$

When 3-iodo-2,6-dimethyl-4-nitropyridine N-oxide (94) was treated with acetyl chloride at $50^{\circ} \mathrm{C}$ for 30 min. afforded 4-chloro-3-iodo-2,6-dimethylpyridine $\mathrm{N}$-oxide $(\mathbf{9 5})^{84-85}$ in $89 \%$ yield. 
<smiles>Cc1c(I)c(Cl)cc([N+](=O)[O-])[n+]1[O-]</smiles>

\subsection{Cycloaddition to dipolar N-O}

The cycloaddition of pyridine $\mathrm{N}$-oxides $\mathbf{9 6 a} \mathbf{b} \mathbf{b}$ to nitrilium salts $\mathbf{9 7 a} \mathbf{a} \mathbf{b}$ in methylene chloride at 0 $23^{\circ} \mathrm{C}$ for $20-45 \mathrm{~min}$. afforded the salts 99a-d in good yield through a reactive intermediate $\mathbf{9 8}^{86}$ (through 1,5-sigmatropic rearrangement).<smiles>[R]c1c([NH2+][O-])c[n+]([O-])c([R])c1[R]</smiles>

$96 a, b$
$\mathrm{R}^{1}-\mathrm{C} \equiv \underset{\mathrm{SbCi} \mathrm{I}_{6}}{\mathrm{~N}-\mathrm{R}^{2}} \frac{\mathrm{CH}_{2} \mathrm{Cl}_{2}}{0-23^{\circ} \mathrm{C}}$<smiles></smiles>

98
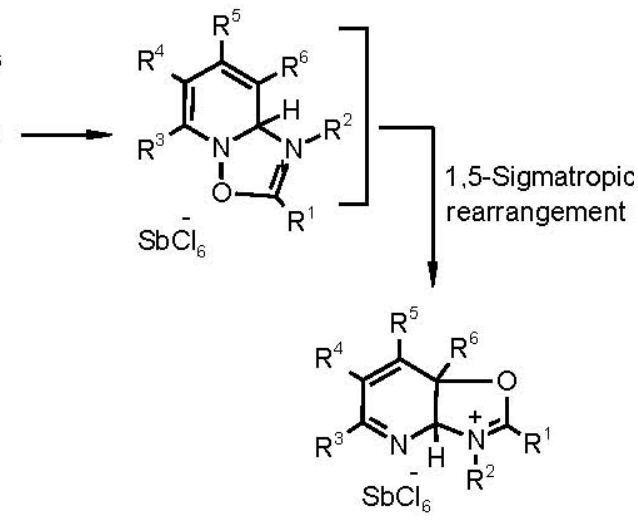

99a-d

The strained 3,3,6,6-tetramethyl-1-thia-4-cycloheptyne (100) reacts at room temperature with pyridine $\mathrm{N}$-oxide (16a) to yield the unstable intermediate 101 which rearranged to the spiro $3 \mathrm{H}-$ azepine derivative 103 in $54 \%$ yield $^{87}$ via the azanorcaradiene (102). 


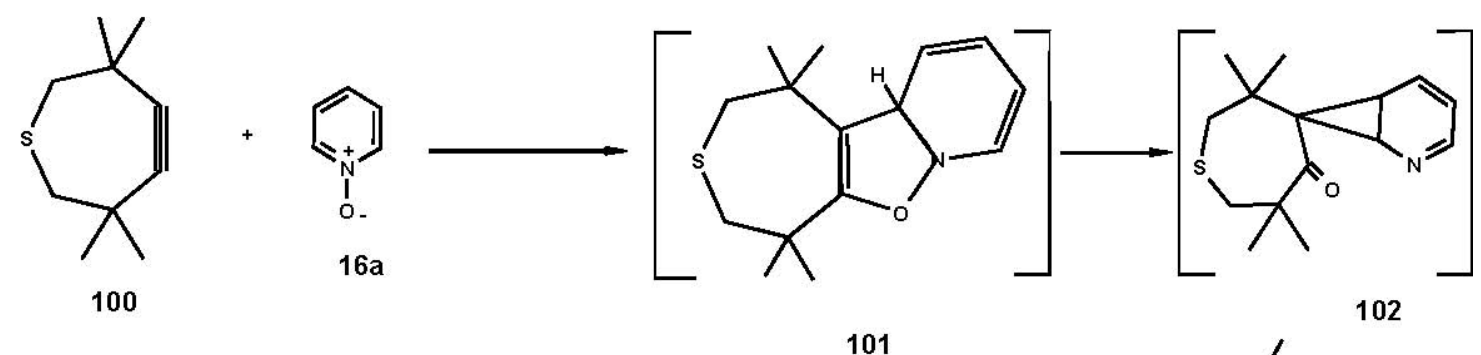

101

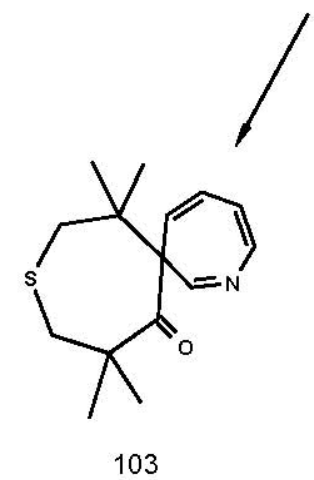

Treatment of pyridine N-oxides 16a and 50 with 2-chloroalkyl- trichlorophosphonium hexachlorophosphorates (104) yields pyridines 15a, 105 and 2-chloroalkylphosphonic dichlorides (106). ${ }^{88}$

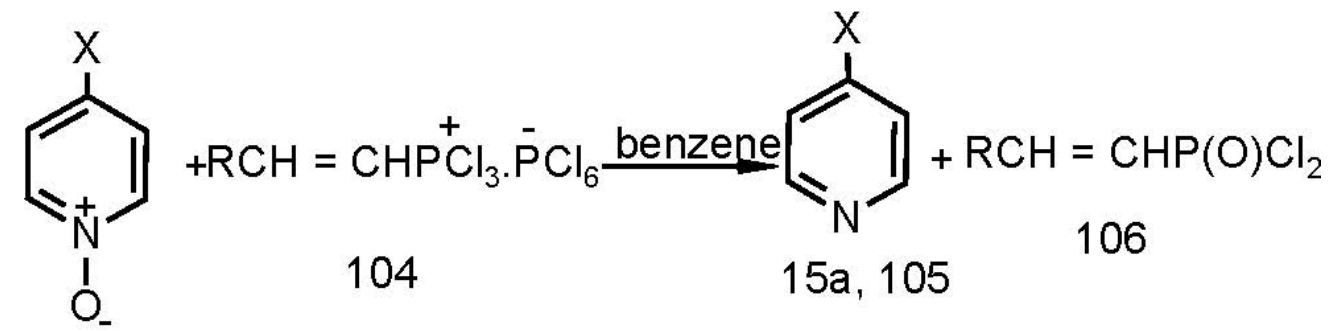

$16 a, 50$

$\mathrm{X}=\mathrm{H}, \mathrm{NO}_{2} ; \mathrm{R}=\mathrm{C}_{6} \mathrm{H}_{5}, \mathrm{OC}_{2} \mathrm{H}_{5}$

$\mathrm{R}=\mathrm{OC}_{4} \mathrm{H}_{9}$

The reaction of tetracyanoethylene (107) with pyridine (15a) even in anhydrous solvents resulted in the formation of pyridinium pentacyano-propenoide (108). ${ }^{89}$

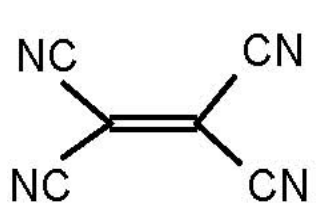

107

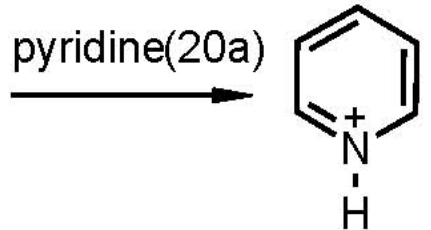

H<smiles>N#CC(C#N)=C(C#N)C(C#N)[N+]#N</smiles>

108 
Based on the above finding, it was expected that the reaction of pyridine $\mathrm{N}$-oxides with tetracyanoethylene in dry benzene corresponds to salts derived from $\mathrm{N}$-oxides and pentacyanopropene.

When pyridine N-oxides 109 was allowed to react with tetracyano-ethylene (107) in dry benzene, a solid begins to precipitate in 1-20 min, and the reaction is completed in 1-2 $\mathrm{h}$ afforded the ion charge transfer compound (110). It was found that the best results were obtained when the reaction was carried out in an ether-ethanol mixture. ${ }^{90}$

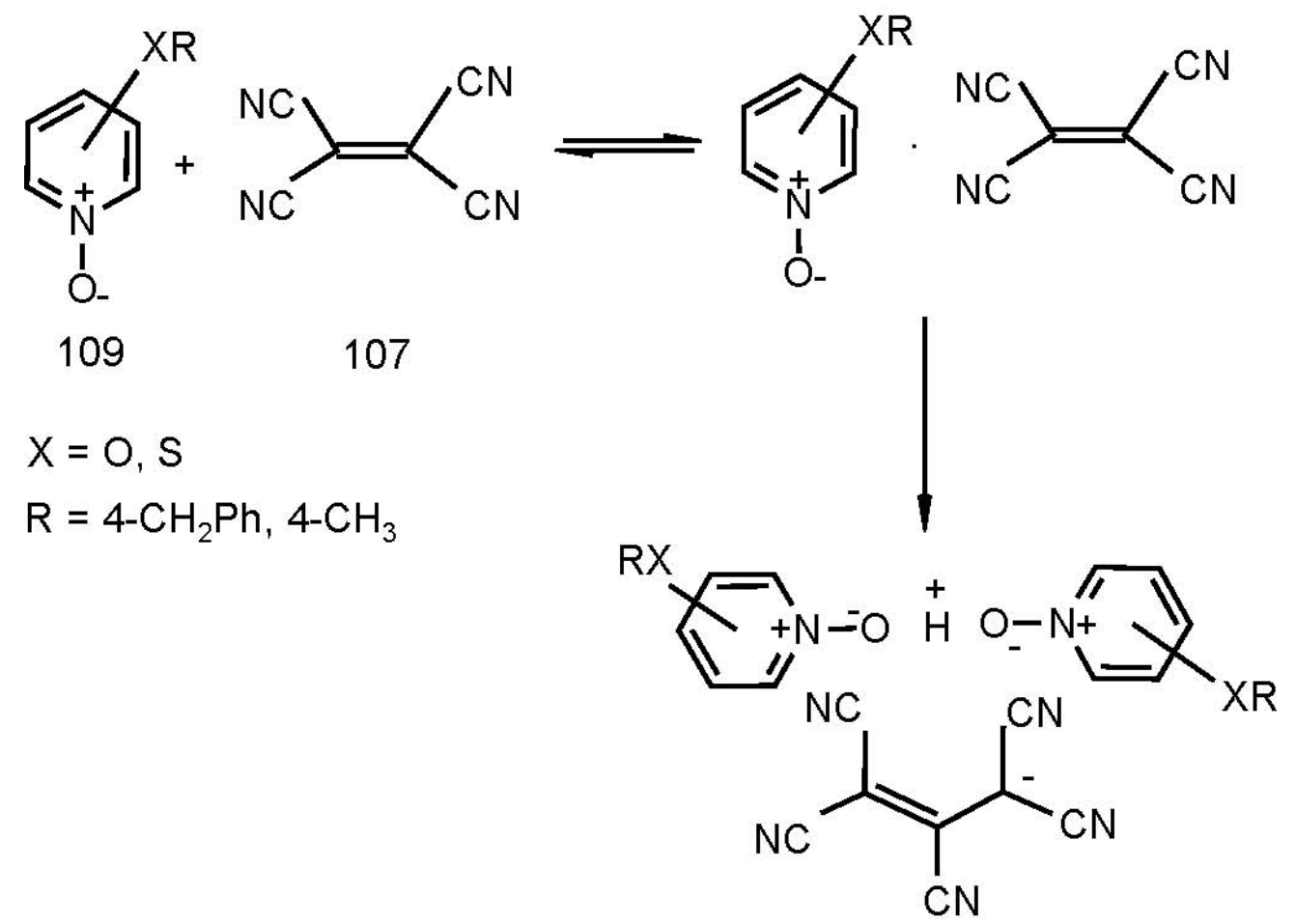

110

The dissolution of the solid products in dioxane, methylene chloride, chloroform, or acetonitrile resulted in the formation of yellow solutions with absorption maxima at 400 and 420 $\mathrm{nm}$. This was attributed to the formation of the charge-transfer band. ${ }^{91-92}$

\section{Conclusions}

Hydrogen peroxide and acetic acid have been used previously for the oxidation of pyridines. This review summarizes the unusual oxidizing agents in quantitative conversion and high chemoselectivity. These reagents (e.g. dimethyldioxirane, oxaziridines) act as oxygen source for the oxidation of pyridine. Also, the use of pyridine N-oxides for the formation of ion charge transfer compounds which is very important in most of the chemical reaction and cycloaddition 
of N-O bond with nitrilium salts was studied.

\section{References}

1. (a) Albini, A.; Pietra, S. Heterocyclic N-oxides CRC Press: Boca Raton. 1991. (b) Albini, A. Synthesis 1993, 263

2. O’Connor,C.J.; Sinn, E.; Carlin, R.L. Inorg. Chem. 1977, 16, 3314.

3. Brycki, B.; Nowak-Wydra, B.; Szafran, M. Magn. Reson. Chem. 1988, 26, 303; Chem. Abstr. 1989, 110, 114156a.

4. Szafran, M.; Brycki, B.; Dega-Szafran, Z.; Nowak-Wydra, B. J. Chem. Soc., Perkin Trans. 1991, 2, 1161.

5. Chmurzynski, L.; Liwo, A.; Tempczyk, A. Z. Naturforsch. 1989, 44b, 1263.

6. Taylor, R.; Kennard, O. J. Amer. Chem. Soc. 1982, 104, 5063.

7. Lutz, B.; van der Maas, J. H.; Kanters, J. A. J. Mol. Struct. 1994, 325, 203; Chem. Abstr. 1995, 122, 133512c.

8. Knuts, S.; Agren, H.; Minaev, B.F. Theochem. 1994, 117, 185; Chem. Abstr. 1994, 121, 178999n.

9. Nakagawa, Y.; Suxuka, I.; and Ito, M. Chem. Phys. Lett. 1993, 208, 453.

10. Lutz, B. T. G.; Jacob, J.; van der Maas, J. H. Vib. Spectrosc. 1996, 12, 197; Chem. Abstr. 1996, 125, 287584b.

11. Abo Aly, M. M.; Morsi, S. Spectrochim.Acta 1992, 48 A, 61; Chem.Abstr. 1992, 116, 255063d.

12. Derek, B. H. R.; Nubar, O.; Bernard, V. Tetrahedron Lett. 1988, 44, 7385.

13. Chucholowski, A. W.; Uhlendorf, S. Tetrahedron Lett. 1990, 31, 1949.

14. Epsztajn, J.; Bieniek, A.; Kowalska, J. A. Tetrahedron 1991, 47, 1697.

15. Epsztajn, J.; Bieniek, A.; Ptotka, M. W.; Suwald, K. Tetrahedron 1989, 45, 7469.

16. Hollins, R. A.; Merwin, L. H.; Nissan, R. A.; Wilson, W. S.; Gilard, R. J.Heterocycl. Chem. 1996, 33, 895.

17. Ritter, H.; Licht, H. H. J.Heterocycl. Chem. 1995, 32, 585.

18. Thellend, A; Battioni, P.; Sanderson, W.; Mansuy, D. Synthesis 1997, 1387.

19. Coperet, C.; Adolfsson, H.; Sharpless, K.B. J. Chem. Soc. Chem. Commun. 1997, 1565.

20. Rudolph, J.; Reddy K. L.; Chiang J. P.; Sharpless K. B. J.Am.Chem.Soc. 1997, 119, 6185.

21. Yudin, A. K.; Sharpless, K. B. J. Am. Chem. Soc. 1997, 119, 11536.

22. Murray, R. W.; Iyanar, K.; Chen, J.; Wearing, J. T. Tetrahedron Lett. 1995, 36, 6415.

23. Zhu, Z.; Espenson, J. H. J.Org. Chem. 1995, 60, 7728.

24. Murray, R. W.; Iyanar, K.; Chen, J.; Wearing, J. T. Tetrahedron Lett. 1996, 37, 805.

25. Goti, A.; Nanelli, L. Tetrahedron Lett. 1996, 37, 6025.

26. Murray, R. W.; Iyanar, K.; Chen, J.; Wearing, J. T. J.Org.Chem. 1996, 61, 8099

27. Yamazaki, S; Bull.Soc.Chem. Jpn. 1997, 70, 877. 
28. Copéret, C.; Adolfsson, H.; Tinh-Alfredo, V. Kh; Yudin, A. K.; Sharpless, K. B. J.Org.Chem., 1998, 63, 1740.

29. Ferrer, M.; Sânchez - Baeza, F.; Messeguer, A. Tetrahedron 1997, 53, 15877.

30. Adam, W.; Briviba, K.; Duschek, F.; Golsch, D.; Kiefer, W.; Sies, H. J. Chem. Soc. Chem. Commun. 1995, 1831.

31. Murray, R. W.; Rajadhyaksha, S. N.; Mohan, L. J.Org.Chem. 1989, 54, 5783.

32. Murray, R. W.; Singh, M.; Rath, N. Tetrahedron Asymmetry 1996, 7,1611

33. Murray, R. W.; Singh, M. J.Org.Chem. 1990, 55, 2954.

34. Murray, R. W.; Singh, M. Tetrahedron Lett. 1988, 29, 4677.

35. Murray, R. W.; Singh, M. Synth. Commun. 1989, 19, 3509; Chem.Abstr. 1990, 113, 96665w.

36. Copêret, C.; Adolfsson, H.; Chiang, P. J.; Yudin, A. K.; Sharpless, B. K. Tetrahedron Lett. 1998, 39, 761.

37. (a) Gregory, J. R.; Edward, J. B. J.Chem.Res.(S) 1993, 412. (b) Cartwright, D.; Ferguson, J. R.; Giannopouls, T.; Varvounis, G.; Wakefield, B. J. Tetrahedron 1995, 51, 12791.

38. Kim, H. R.; Jung, J. H.; Kim, J. N.; Ryu, E. K. Synth. Commun. 1990, 20, 637; Chem.Abstr. 1990, 113, 77823e.

39. Kim, H. J.; Kim, H. R.; Kim, J. N.; Ryu, E. K. Bull. Korean Chem. Soc. 1990, 11,184; Chem. Abstr. 1990, 113, 190453x.

40. Chung, K. H.; Kim, K. M.; Kim, J. N.; Ryu, E. K. Synth. Commun. 1991, 21, 1917; Chem.Abstr. 1991, 115, 231815d.

41. Kim, H. R., Chung, K. H., Kim, H. J.; Ryu, E. K. Bull. Korean Chem. Soc. 1992, 13, 579. Chem. Abstr. 1993, 118, 168910a.

42. Kim, K. M.; Chung, K. H.; Kim, J. N.; Ryu, E. K. Synthesis 1993, 283.

43. Rhie, S. Y.; Ryu, E. K. Heterocycles 1995, 41, 323.

44. Bremner, D. H.; Sturrock, K. R.; Wishart, G.; Mitchell, S. R.; Nicoll, S. M.; Jones, G. Synth. Commun. 1997, 27, 1535; Chem. Abstr. 1997, 126, 343469c.

45. Fieser, M. Reagents for organic synthesis Vol. 14; Willey: New York, 1989, p 290.

46. Greenhalgh, R. P. Synlett 1992, 235; Chem.Abstr. 1992, 117, 7461u.

47. Bernardi, R.; Novo, B.; Resnati, G. J. Chem. Soc., Perkin Trans. 1 1996, 2517.

48. Nesi, R.; Giomi, D.; Papaleo, S.; Bracci, S.; Dapporto, P. Synthesis 1988, 884.

49. Nesi, R.; Giomi, D.; Papaleo, S.; Bracci S.; Dapporto, P. J.Org. Chem, 1989, 54, 706.

50. Nesi, R.; Giomi, D.; Papaleo, S.; Corti M. J. Org. Chem, 1990, 55, 1227.

51. Nesi, R.; Giomi, D.; Papaleo, S.; Turchi, S. J.Org. Chem. 1992, 57, 3713.

52. Handa, Y.; Inanaga, J.; Yamaguchi, M. J. Chem. Soc., Chem. Commun. 1989, 298.

53. Aoyagi, Y.; Inariyama, T.; Arai, Y.; Tsuchida, S.; Matsuda, Y.; Kobayashi, H.; Ohta, A. Tetrahedron 1994, 50, 13575.

54. Aoyagi, Y.; Yoshimura, M.; Tsuchbuchi, T.; Kawamata. S.; Tateno, H; Asano, K.; Nakamura, H; Obokata, M.; Ohta, A.; Kodama, Y. J. Chem. Soc., Perkin Trans. 1 1995, 689.

55. Aoyagi, Y.; Manabe, T.; Ohta, A.; Kurihara, T.; Pang, G-L. Tetrahedron 1996, 52, 869. 
56. Aoyagi, Y.; Asakura, R.; Kondoh, N.; Yamamoto, R.; Kuromatsu, T.; Shimura, A.; Ohta, A. Synthesis 1996, 970.

57. Aoyagi, Y.; Maeda, M.; Moro, A.; Kuboto, K.; Fujii, Y.; Fukaya, H.; Ohta, A. Chem. Pharm. Bull. 1996, 44, 1812; Chem.Abstr. 1996, 125, $328081 \mathrm{f}$.

58. Aoyagi, Y.; Tanaka, W.; Ohta, A. J. Chem. Soc., Chem. Commun. 1994, 1225.

59. Nakajima, M.; Sasaki, Y.; Hashimoto, Sh. Tetrahedron Lett. 1998, 39, 87.

60. Morimoto, Y.; Kurihara, H.; Kinoshita, T. Chem. Lett. 1998, 829.

61. Singh, B.; Lesher, G. Y.; Pennock, P. O. J. Heterocycl.Chem. 1990, 27, 1841.

62. Balicki, R.; Kaczmarek, L.; Malinowski, M. Synth. Commun. 1989, 19, 897; Chem. Abstr. 1990, 112, 20885b.

63. Balicki, R. Gazz. Chim. Ital. 1990, 120, 67.

64. Konwar, D.; Boruah, R. C.; Sandhu, J. S. Chem.Ind. London 1989, 191.

65. Konwar, D.; Boruah, R. C.; Sandhu, J. S. Synthesis 1990, 337.

66. Aoyagi, Y.; Abe, T.; Ohta, A. Synthesis 1997, 891.

67. Malinowski, M.; Kaczmarek, L. J. Prakt. Chem. 1988, 330, 154.

68. Kaczmarek, L.; Malinowski, M.; Balicki, R. Bull. Soc .Chem. Belg. 1988, 97, 787; Chem.Abstr. 1989, 111, 57487d.

69. Kaczmarek, L.; Balicki, R.; Malinowski, M. J. Prakt. Chem. 1990, 332, 423.

70. Alker, D.; Ollis, W. D.; Shahriari-Zavareh, H. J. Chem. Soc., Perkin Trans. 1 1990, 1623.

71. Alker, D.; Ollis, W. D.; Shahriari-Zavareh, H. J. Chem. Soc., Perkin Trans. 1 1990, 1637.

72. Alker, D.; Mageswaran, S.; Ollis, W. D.; Shahriari-Zavareh, H. J.Chem. Soc.,Perkin Trans.1 1990, 1631.

73. Haber, H.; Hagen. V.; Schlender, M. J. Prakt. Chem. 1991, 333, 637.

74. Chambers, R. D.; Hall, C. W.; Hutchinson, J.; Millar, R. W. J. Chem. Soc., Perkin Trans.1 1998, 1705.

75. Ryzhakov, A. V.; Vapirov, V. V.; Rodina, L. L. Zh.Org.Khim. 1991, 27,955; Chem.Abstr. 1992, 116, 20494f.

76. Mongin, O.; Rocca, P.; Thomas-dit-Dumont, L.; Trécourt, F.; Marsais, F.; Godard, A.; Quéguiner, G. J.Chem.Soc. Perkin Trans. 1 1995, 2503.

77. Estel, L.; Linard, F.; Marsais, F.; Godard, A.; Quéguiner, G. J. Heterocycl. Chem. 1989, 26, 105.

78. Trécourt, F.; Mallet, M.; Mongin, O.; Gervais, B.; Quéguiner, G. Tetrahedron 1993, 49, 8373.

79. Talik, T.; Talik, Z. Pr. Nauk. Akad. Ekad. Ekon im. Oskara Langego Wrolawiu 1987, 397, 141; Chem. Abstr. 1988, 109, 190207.

80. Matveev, A. A.; Koblik, I. V.; Popov, A. F.; Savelova, V. A.; Matvienko, V. N. Russ. J. Org. Chem. 1998, 34, 271; Chem.Abstr. 1998, 129, 330358c.

81. Popov, A. F.; Matveev, A. A.; Koblik, I. V.; Savelova, V. A.; Matvienko, V. N. Zh.Org. Khim. 1996, 32, 609; Chem.Abstr. 1996, 125, 327843u.

82. Eggers, L.; Grahn, W. Synthesis 1996, 763. 
83. Hanuza, J.; Maczka, M.; Waskowska, A.; Oganowski, W.; Ban-Oganowska, H.; Van der Maas, J. H.; Lutz, E. T. G. J.Chem.Soc., Perkin Trans. 2 1997, 2039.

84. Bougeard, D.; Burie, J. R.; Quy Dao, N.; Hennion, B. Spectrochim. Acta 1995, 51A, 21; Chem.Abstr. 1995, 122, 132486k.

85. Ban-Oganowska, H.; Spectrochim. Acta 1994, 50A, 1007; Chem.Abstr. 1994, 121, 34653x.

86. Hitzler, M. G.; Freyhardt, C. C.; Jochims, J. C. J.Prakt.Chem. 1996, 338, 243.

87. Lindner, H. J.; Krebs, A.; Forster, J.; Sinnwell, V. Heterocycles 1997, 45, 811.

88. Mitrasov Yu., N.; Anisimova, E. A.; Kolyamshin, O. A.; Kormachev, V. V. Russ. J. General. Chem. 1998, 68, 153; Chem.Abstr. 1998, 129, 216678g.

89. Shine, H. J.; Goodin, R. D. J.Org. Chem. 1970, 35, 949.

90. Alekseeva, O. O.; Rodina, L. L.; Ryzhakov, A. V.; Korneev, S. M. Russ. J.Org. Chem. 1997, 33, 1320; Chem. Abstr. 1998, 129, 148893w.

91. Matsuoka, T.; Harano, K. Tetrahedron 1995, 51, 6451.

92. Rodina, L. L.; Ryzhakov, A. V. Heterocycles 1995, 40, 1035. 